AgnieszKa IzDebsKa

Uniwersytet Łódzki*

(iD) https://orcid.org/0000-0002-6253-8397

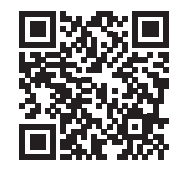

\title{
Metafictional potentiality of detective fiction and the metaphysical detective stories
}

\begin{abstract}
The article examines metatextual devices appearing within texts whose genre affiliation the implementation of the detective novel convention - is unarguable. Such use of selfreferential strategies is juxtaposed with their applications in texts that in English-language reflection on postmodern and modernist novels are defined as metaphysical detective stories. The article examines the genre aspects of the use of these devices and their consequences for the location of a crime novel within contemporary popular culture.
\end{abstract}

popular literature, crime fiction, detective fiction, metaphysical detective story 
* Katedra Teorii Literatury, Uniwersytet Łódzki ul. Pomorska 171/173, 90-236 Łódź e-mail:agnieszka.izdebska@uni.lodz.pl 
The authors of an introduction to a collection of texts on crime fiction as world literature write: "Crime fiction is certainly one of the most widespread of all literary genres. [...] Crime novels are read worldwide, and crime writers around the world inspire which other" (Nilsson, Damrosch \& D'hean 2017: 2). For those reasons the genre "offers a particularly rich area of inquiry" in reflections on "world literature in relation to society" (Nilsson, Damrosch \& D'hean 2017: 2).

Also Gigliola Sulis stresses in her text on crime fiction as a polymorphic genre:

Crime fiction has become one of the most widely available forms of storytelling and as such is both a powerful catalyst of global imagination and privileged framework for the interpretation of society. Crime stories are a vehicle for cultural exchange in the broadest of senses. They move with apparent ease from one country to the next, in and out of different languages, and they are also reproduced and recreated through various cultural media. (Sulis 2019: 11)

And probably, among other things, that is why the status of this genre has changed from "a guilty pleasure" of researchers to the subject of literary studies (Priestman 2003: 1). Obviously, it is also linked to the fact that "the presumed barriers between 'high' and 'low' literature have been progressively dismantled" (Priestman 2003: 1). While I am not challenging these statements, I would nevertheless like to draw attention to those aspects of the convention that bring out the self-referential potential of the genre, not its abilities of making social or existential diagnoses.

There are a lot of possible answers to the question about the reasons of the genre popularity, but a particularly convincing one has been proposed by a British detective fiction writer, Antony Horowitz, who says in a fictional interview with himself included in his novel The Sentence is Death:

Murder writing is unique in some ways. Certainly, I can think of no genre where the reader is so close $[. .$.$] with the main character - the detective. They have the same aim, which is to discover$ the truth [...] whodunit offers a particular sort of satisfaction. When you get to the end of the book, all the i's are dotted and the t's are crossed. [...] Right now the world is a very confusing place with a fast-moving, 24-hour news agenda, social media, fake news. We suffer from a surfeit of information and it's often hard to be sure what is really happening. With a whodunit, you get certainty and there is a real comfort in that. (Horowitz 2019: 382-383) 
I am citing his words not only because I am going to analyze Horowitz's novels later in the paper, but also because the cognitive dimension of crime fiction is exposed here. That is why it is really interesting that expansion of devices characteristic for the genre outside of its borders is associated with exposing cognitive uncertainty. Thus, the subject of my considerations in this text will be the consequences of various metatextual games with the conventions of crime fiction played by many writers. I am interested mainly in genre-related issues in this context.

There is a number of terms used to describe the phenomenon of subverting traditional devices of detective fiction: "metafictional detective fiction" (Malmgren 2001: 113), "antidetective story", "deconstructive mysteries" and, last but not least, "metaphysical detection" (Merivale \& Sweeney 1999: 2-4). In his Constructing Postmodernism, when writing about The Name of the Rose, Brian McHale cites the term "anti-detective story" used by William Spanos and defined as one that 'evoke[s] the impulse to 'detect' ... in order to violently frustrate it by refusing to solve the crime" (Spanos 1972: 154) or, as McHale puts it, "by inverting, suppressing, or occluding other essential features of the detective-story model (crime, victim, detective), ultimately by undermining its very rationality" (McHale 1992: 150). As a result, "by deliberately crippling the detective story's epistemological structure, these texts [...] evacuate the detective story of its epistemological thematics" (McHale 1992: 151). The author of Constructing Postmodernism refers also to Stefani Tani study, The Doomed Detective: The Contribution of the Detective Novel to Postmodern American and Italian Fiction, where "antidetective" stories are divided into three categories: the innovative (e.g. Umberto Eco's The Name of the Rose), the deconstructive (e.g. Thomas Pynchon's The Crying of Lot 49) and the metafictional (e.g. Italo Calvino's If on a Winter's Night a Traveller). In the volume Detecting Texts. The Metaphysical Detective Story from Poe to Postmodernism edited by Patricia Merivale and Susan E. Sweeney, the phenomenon mentioned above is defined as follows:

A metaphysical detective story is a text that parodies or subverts traditional detective-story conventions - such as narrative closure and the detective's role as surrogate reader-with the intention, or at least the effect, of asking questions about mysteries of being and knowing which transcend the mere machinations of the mystery plot. Metaphysical detective stories often emphasize this transcendence, moreover, by becoming self-reflexive (that is, by representing allegorically the text's own process of composition). (Merivale \& Sweeney 1999: 2)

I am so much not concerned with the terminological dispute, but I agree with Merivale and Sweeney's statement that they prefer the name "metaphysical detection" because "it indicates explicitly how late modernist [...] and postmodernist writers have altered the detective story", that is they emphasize epistemological and ontological questions: "What, if anything, can we know? What, if anything, is real? How, if at all, can we rely on anything besides our own constructions of reality? In this sense, metaphysical detective stories are indeed concerned with metaphysics" (Merivale \& Sweeney 1999: 4). There are numerous texts cited in that context: e.g. City of Glass by Paul Auster, many of J.L. Borges' short stories (e.g. Death and Compass, The Garden of Forking Paths, Theme of the Traitor and the Hero, The Approach to Al-Mu'tasim), Absalom, Absalom! and The Rose for Emily by William Faulkner, La Jalousie, La Maison de rendez-vous and Dijnn by Alain Robbe-Grillet. It is not my intention either to take a stand on whether employing deconstructed conventions of a crime novel is a typically modernist or postmodernist trick (McHale 1990: 190), but many critics rather agree that many postmodern novels use this device (The Name of the Rose and The Crying of Lot 49 are standard 
examples). However, I cannot agree with Heather Worthington's statement: "Despite the apparent complexities of postmodernism and the potential it seems to offer for disengagement with the world and lived experience, its use in relation to crime fiction seems rather to draw it back into engagement if not with the real, with real issues" (Worthington 2011: 180-181). In my opinion, it draws novels of that kind directly to textuality itself.

A particularly interesting group of texts that can be called metaphysical detective stories are those that employ metalepsis, namely — according to Gerald Genett's definition - every intrusion of an extradiegetic narrator or recipient of the narrative into the diegetic world (or also characters from diegesis into the metadiegetic world) (Swoboda 2005: 184). Undoubtedly, the most famous usage of this device is the short story Continuity of Parks by Julio Cortazar, where in the end readers realize that the main protagonist is going to be murdered by two characters from the novel he is reading. Olga Tokarczuk, Polish female writer and Nobel Prize winner, also wrote a narrative - Otwórz oczy, już nie żyjesz (Open your eyes, you are dead) - based on the concept of metalepsis. In her story, the main character, a compulsive reader of detective fiction decides to intervene in the plot of the novel she is reading, bored by the fact that nothing has happened for too long. She becomes a murderer. As a result, in the finale of the story, a police car stops in front of the reader's house and someone gets out. The heroine seems to recognize the man as the detective from the novel. And finally, the last example on the list of such texts that could go on indefinitely: The Athenian Murders by José Carlos Somoza.

The novel (which could also be classified as historical crime fiction) consists of two texts: the main narrative, where detective Heracles Pontor (sic!) is investigating a series of mysterious deaths Athens, and extensive footnotes, in which the translator of the manuscript comments the text and the plot. In the finale of the book, when the corpse of a beautiful young woman is found, soldiers hear the detective muttering: "Why? Why? Why?.' And here is the last footnote number 140: “'the text is incomplete!' Why do you think that?' asks Manolo. It ends with the sentence: 'Then, the Translator said'. 'No,' says Manolo.” (Somoza 2003: 309). A heated argument between the two concludes as follows:

Stunned, furious, I pounce on Manolo. I try to strike him and escape, but all I manage to do is tear off his face. His face is another mask. But behind it, there's nothing, darkness. His clothes fall, limp, to the floor. The table at which I've been working disappears. So does the bed and the chair. The walls of the cell vanish. I'm plunged into darkness. "Why? Why? Why?' I ask. The space allocated to my words shrinks. I become as marginal as my footnotes. The author decides to end me here. (Somoza 2003: 312)

Nevertheless, Somoza's novel ends with Epilogue, where we can hear a voice of the real author of the story, who says:

I simply wished to tease them a little (forgive me, my intentions were good), to move them, but also to raise my voice (as a poet, not a philosopher) and cry: "Stop looking for hidden ideas, final keys and ultimate meanings! Stop reading and live! Come out of the text! What do you see? Nothing but darkness? Stop searching!' I don't believe they will listen. They'll continue scurrying about, as tiny as letters of the alphabet, obsessed with finding the Truth through words and dialogues. (Somoza 2003: 314) 
The final sentence of the novel reads a s follows: "The end of The Athenian Murders, written by Philotextus of Chersonnese in the year that Arginides was archon, Demetriate was sybil, and Argelaus was ephor" (Somoza 2003:314).

Undoubtedly, Somoza's novel meets all the requirements of a metaphysical detective story because it poses both epistemological and ontological questions and ostentatiously exposes the metatextual level of a narrative. As in all the examples mentioned above and in the case of Somoza's novel, we understand why the author employs a convention that exposes order rather than the chaos of the world and in which of its aspects he subverts the genre. However, as all the above-listed novels, The Athenian Murders is not detective fiction, which means that it does not belong to:

A type of fiction cantered around the investigation of a crime that focuses attention on the method of detection by structuring the story around a mystery that appears insoluble through normal investigative methods. For this reason it is also known as mystery fiction. Detective fiction, by focusing on the method of detection, simultaneously focuses attention on the figure of the methodical detective: that is, the detective who follows a particular method. (Scaggs 2005: 144)

I am quoting this particular definition of the genre just for practical reasons: it is not my intention to analyze the possible nuances of various definitions of the genre - I am interested in, as I have already mentioned, metatextual strategies appearing in the genre itself. Therefore, Scaggs's definition offers a useful starting point for my subsequent considerations.

Moreover, the crucial feature of detective fiction is, to quote Malmgren, that "it proposes to reproduce faithfully the gritty feel of the 'real world,' it tries not to call attention to itself or its literariness; it uses signs as transparent vehicles that allow us to see directly the world they re-present" (Malmgren 2011: 113). In addition, one of the features of the crime story is also the "ease" of reading, which seems to be in contradiction with all metatextual tricks (Kraska 2013: 29). However, many researchers emphasize that detective stories writers - especially in so-called Golden Age - quite often call readers' attention to the genre itself as signifying practice. The novel frequently cited in this context is The Body in the Library by Agatha Christie, where characters discuss the probability of finding a dead body in the library in the morning - the central event of the narrative. Peter Lovsey also used a similar device in his novel Bloodhounds from the detective Diamond series, where the eponymous policeman says in the beginning: "A good old-fashioned mystery will do me. I don't ask for bodies at every turn. Just one will do if it presents a challenge. Is that too much to ask in Bath?" (Lovesey 1996: 17). He is almost immediately assigned to a case in the style of the locked-room mystery (most closely associated with the Golden Age; Scaggs 2005: 146) and the suspects are members of the crime novel enthusiasts club, "Bloodhounds", fiercely discussing the superiority of certain plot solutions over other. As a result, in addition to the pleasure of following the investigation, we also receive a solid lecture on the history of the British crime fiction. There is no doubt that Lovesey's novel, despite playing with the convention, remains within its boundaries. Therefore, in my article I discuss such texts that use metafictional devices and make the subject of presentation the genre itself, but are still classified as detective fiction. In this respect, the novels by Anthony Horowitz seem particularly appealing.

The writer is the author of numerous detective novels and UK's most popular TV series: Midsummer Murders and Foyle's War. Undoubtedly, his diverse experiences within the literary genre, in particular the many variants of a detective story, resulted in playing different 
games with the requirements and limitations of this form. Thus, Horowitz constructs the genre of detective fiction in his texts and at the same time thematizes it. For example, his novels The House of Silk (2011) and Moriarty (2014) refer to Sherlock Holmes narratives (the issue of such apocryphal texts will become the subject of my comments later in this article), but an analysis of two of his novels seems to be particularly important for reflection on the metatextual potential of the genre: Magpie Murders (2016) and The Word is Murder (2017). The latter is the first in the series featuring detective Hawthorne and the author himself followed by The Sentence is Death (2018).

A construction of Magpie Murders is based on well-known device mise-en-abyme, framing one story within another. The plot starts when the main character and the narrator - it is a first person-narrative - begins to read the novel Magpie Murders, "number nine in the much-loved and world-bestselling Atticus Pünd series" (Horowitz 2016: 1). The protagonist, an editor, warns readers that the novel has changed her life, literally:

As far as I'm concerned, you can't beat a good whodunit: the twist and turns, the clues and red herrings and then, finally, the satisfaction of having everything explained to you in a way that makes you kick yourself because you hadn't seen it from the start. That was what I was expecting when I began. But Magpie Murders wasn't like that at all. I hope I don't need to spell it out any more. Unlike me, you have been warned. (Horowitz 2016:3)

Then the novel begins and we can read the first page of Magpie Murders. An Atticus Pünd Mystery written by Alan Conway. This part of the book has a different pagination and typescript, it also contains a note about the author and quotes from press reviews of previous volumes of the series. As readers, we follow the actions of the novel's detective until at certain point it turns out that the manuscript is incomplete: there is no conclusion and no solution to the crime mystery. Moreover, the author seems to have committed suicide, but our heroine-editor of course suspects that he was actually murdered: "You'd have thought that after twenty years editing murder mysteries I'd have noticed when I found myself in the middle of one. Alan Conway had not committed suicide. He had gone up to the tower to have breakfast and someone had pushed him off. Wasn't it obvious?" (Horowitz 2016: 60). She begins to play the role of an amateur sleuth. Among other things, she draws up a list of possible suspects and considers their motives - she does exactly the same thing when she discovers the missing end of the novel she was reading.

The protagonist soon realizes the differences between detective fiction and investigation: "It's one thing reading about detectives, quite another trying to be one" (Horowitz 2016: 156). In the chapter entitled Detective work there are a lot of metatextual remarks on the genre itself. One of them sounds familiar:

Whodunits are all about truth: nothing more, nothing less. In the world full of uncertainties, is it not inherently satisfying to come to the last page with every I dotted and every t crossed? The stories mimic our experience in the world. We are surrounded by tensions and ambiguities, which we spend half our life trying to resolve and we probably be on our deathbed when we reach that moment when everything makes sense. Just about every whodunit provides that pleasure. It is the reason for their existence. It's why Magpie Murders was so bloody irritating. (Horowitz 2016: 156) 
As we remember, the author repeats those remarks in his fictional interview. But, ultimately, both novels, the one written by the fictional Conway and the second, whose author is the real Horowitz, meet all the requirements of detective stories: we find out who the committed the murder and why in both fictional worlds. The genre order has been restored.

The novel is infused with the spirit of Agatha Christie. One of the witnesses of the conversation held in a restaurant and important for the investigation is Christie's grandson. The protagonist wants him to repeat what he heard: "I found it rather endearing that Mathew hadn't asked me why I was interested in what had happened. He had lived much of his life in the world created by his grandmother and the way he saw it, detectives asked questions, witnesses answered them" (Horowitz 2016: 80). Moreover, they both discover that Conway's Magpie Murders "pays quiet homage to Agatha Christie at least half a dozen times" (Horowitz 2016: 82 ), not only by using the old nursery rhyme but because it "deliberately imitates a device that Christie used many times" (Horowitz 2016: 82-83).

Magpie Murders features something that would later become one of the main themes in Horowitz's subsequent novel: the relationship between real police work and real crimes and the investigations of fictitious detectives prosecuting sophisticated and cunning criminals. In a conversation with the main character, the policeman investigating the death of Alan Conway points out her excessive imagination born in the world of crime novels, which makes her unable to see that the writer committed suicide:

All these murders on TV — you'd think people would have better things to do with their time. [...] People don't plan these things. They don't sneak into their victims houses and throw them off the roof and then send letters hoping they're going to be misinterpreted, as you put it. They don't put wigs and dress up like they do in Agatha Christie. [...] All the murderers I've met have been thick as shit. Not clever people. Not posh or upper class. [...] And you know how we catch them? [...] We catch them on CCTV. [...] Maybe one day you should publish the truth although "I'm telling you, nobody would want to read it. (Horowitz 2016: 136-137)

Fortunately, we read the double Magpie Murders — the fictional and 'unreal' story of a murder mystery, that is detective fiction. That is why our protagonist, an amateur sleuth, must be right, the letter is fake and a sophisticated killer is behind everything.

The plot of The Word is Murder - another Horowitz's novel I would like to cite here starts when an elderly lady is killed six hours after making arrangements regarding her own memorial service at the funeral home. The case is investigated by detective Daniel Hawthorne as a police consultant. He is accompanied by Anthony Horowitz, who is supposed to write down the story. Thereby, The Word is Murder is a story about writing the story of a mystery with the author as one of characters. Moreover, once again, it is a novel about the convention itself. To put it in more detail, Horowitz makes the subject of presentation the main protagonist - a detective, the way of narrating, and - last but not least - confronts the laws governing the genre with reality outside the depicted world. What is crucial, the novel is not a pastiche, and therefore it remains within the frame of the genre.

The figure of an author as one of the characters in the story is one of the subjects of the narrative. Horowitz: "it worries me to be so very prominent in these pages. But this time round I have no choice. I'm writing exactly what happened" (Horowitz 2017: 12). 
If I walked away, Hawthorne would just go to another writer and what would be the result of that? I'd end up as a minor character, nothing more than a sidekick in someone else's book, which would actually be considerably worse than being a real character in one of my own. They would be able to do anything they likes They could me look like a complete idiot if they wanted. On the other hand, if I wrote the book, I would have control. (Horowitz 2017: 386-387)

However, this phrase: "I'm writing exactly what happened" established the entire convention of the novel and makes the confrontation of fiction vs reality the subject of presentation. It also means that the genre itself becomes the topic of the story. It applies to such elements of the structure as the building of the main character - detective Hawthorne.

The fictious Horowitz, writing the novel we read, is disappointed in his detective hero: "If I had sat down to write an original murder mystery story, I wouldn't have chosen anyone like Hawthorne as its main protagonist. I think the world has had enough of white, middleaged, grumpy detectives and I'd tried to think up something more unusual. A blind detective, a drunk detective, an OCD detective, a psychic detective... they'd all been done, but how about a detective who was all four those things?" (Horowitz 2017: 97). Moreover, Hawthorne seems not to understand in what kind of narrative he is featured. When he does not want to talk about himself and stubbornly repeats: "Nobody's interested in me", his partner tries to explain to him how important he is as an element of the genre:

They're not called murder victim stories. They're not called criminal stories. They're called detective stories. There's a reason for that. I'm taking a big risk here. [...] So getting to know you matters. If I know you, if I can find something that makes you more ... human, at least that's a start. (Horowitz 2017: 61)

But the "real" detective in a role of a literary protagonist becomes problematic. During their cooperation the author discovers that his character/partner is a homophobe. The narrator realizes with a panic that "for twenty-first-century novelist to create a character who is homophobic, it will be much more sensible if that character is palpably vile, the villain of the piece" (Horowitz 2017: 99-100). Ultimately, he decides to learn more about the detective: "I would investigate the investigator" (Horowitz 2017: 102). In consequence, there are multiple investigations in the novel.

Almost in the end of it the author and the narrator contemplate — belatedly, in a way the chosen form of narrative:

In retrospect, it's a pity that I decided to write all this in the first person as it will have been obvious all along that I wasn't going to die. It's a literary convention that the first-person narrator can't be killed although it's true that one of my favourite films, Sunset Boulevard, breaks all the rules with its opening shot [...] I wish there had been some way to disguise the fact that I would make it through to this chapter and wake up in the A\&E Unit of Charring Cross Hospital [...], but I'm afraid I couldn't think of one. So much for suspense! (Horowitz 2017: 357)

By the way, in Moriarty Horowitz also plays with the convention of the first person narrative in the genre. The writer not only repeats Agatha Christie's famous device from her novel The Murder of Roger Aykroyd, where the narrator is the murderer, but also hides the identity of the storyteller, who turns out to be the mortal enemy of Sherlock Holmes - professor Moriarty 
himself. He declares: "It would appear, my dear reader, that I have deceived you — although, in truth, you are not very dear to me and anyway, I have taken the greatest pains to avoid any deception at all. That is to say, I have not lied" (Horowitz 2014: 327).

Thus, in The Word is Murder we have detective fiction that pretends to be 'a real' story, just a report of what really happened: "I'm often asked if I start writing a book without knowing the end. For me, it would be like building a bridge without knowing what's got to reach. This time everything had been given to me and it was more a question of configuration than creation and I wasn't entirely happy with some of the materials" (Horowitz 2014: 375). As a result, we have detective fiction that pretends not to be fiction at all.

A large group of texts that undoubtedly could be defined as detective novels are apocryphal. It means that they are based on intertextual devices that refer to texts from the Western cultural canon (Szajnert 2014: 207). For example, there are numerous 'Holmesonian' works, to list only a few: the Irene Adler series by Carole Nelson Douglas (e.g. Good Night, Mr. Holmes, Good Morning, Irene or Another Scandal in Bohemia), Laurie R. King's series featuring Mary Russell, Holmes's wife (sic!) as the heroine (e.g. The Beekeeper Apprentice and A Letter of Mary), Mycroft Holmes by Karim Abdul Jabar and Bonnie MacBird's trilogy $A$ Sherlock Holmes Adventure (Art in the Blood, Unquiet Spirits and The Devil's Due). The latter is quite interesting, as the author employs the old device of the fictional editor discovering a manuscript in an old trunk - here, she finds doctor Watson's unknown writings hidden amongst medical documents at Wellcome Library. Speaking of finding old manuscripts: Stephanie Barron used an analogical device in her series about investigating Jane Austen - the author finds "missing" journals from an unknown period of Austen's life. And, as Anita Vickers stresses, "just suppose that the missing piece of the biographical puzzle is that she was not writing fiction because she was busy solving mysteries" (Vickers 200: 213). Incidentally, I cannot agree with Vickers's commentary on Barron's novels: "The mixture of biography, literary scholarship, and detective fiction leads to a re-invention of biography" (Vickers 2000: 214). In my opinion, this mixture primarily determines the variety of the detective fiction. But Barron's novels offer another version of apocryphal construction: an alternative version of famous people's biographies. Michael Gregorio used a similar device in his novel Critique of Criminal Reason featuring - why are we not surprised? - Emmanuel Kant trying to solve the mystery of serial killing shocking Königsberg. There is no old trunk here, but the story we read is written by a court clerk and Kant's former student. Thus, the manuscript establishes a narrative frame, in which we can easily recognize a device typical for a first person narrative, where author of the manuscript reveals his intentions and signals the differences between himself writing and himself being the hero of the story:

My hope was to inform the world of a working method that would be of practical use to any magistrate called upon to solve a murder. In short, I set out to write a treatise for which the greatest son of Eastern Prussia had already supplied a tentative, if ironic title. But this noble plan was abruptly terminated after those few introductory lines [...]. Indeed, the simpleton who wrote those lines, and the man writing these, are two such alien creatures - despite the claims of common sense and the evidence I see in my shaving-mirror - that I feel called to question whether they are the self-same person. The sights I saw in Königsberg will haunt me for the remainder of my days on earth... (Gregorio 2007: 2) 
Despite playing games with the biography convention, Gregorio's novel is, of course, an example of detective fiction, or, precisely speaking, its subgenre called historical detective fiction.

There are a lot of metatextual devices used in the genre that is considered heavily conventional - in the text have I mentioned only a few of them. The important question is why in so many texts authors decided to make the subject of presentation not only the mystery itself but also the genre. This may be because readers that choose detective fiction form a more complex and hybrid group than could be expected - after all, similar trends can be seen in the film's realizations of the genre, e.g. in Memento by Christopher Nolan, The Conversation by Francis Ford Coppola or Sleuth by Kenneth Branagh (a remake of Joseph L. Mankiewicz's film). In this context, the title of Thom Eberhardt's film, Without a Clue (a story of a genius detective and writer doctor Watson, forced by the success of his short stories to hire a ham actor and alcoholic to pretend to be Sherlock Holmes) is obviously a play on the crucial element of the genre and at the same time creates an apocryphal version of Holmes' adventures. Moreover, all these games with the convention testify not only to its liveliness and diversity, but also the fact that the relationship between a variation on a known theme and an innovation in this genre is a bit more complex that is assumed (Kraska 2013: 50).

And yet, in the text mentioned in the article, Nilsson, Damrosch and D'haen emphasize, "The globalized and hybridized genre of crime fiction, dealing with universal questions about life and death, crime and punishment, conflicting values and moral systems, is known for portraying the darker sides of society and formulating a social critique upon its own native context" (4). Hovever, it is possible that one of elements of globalization of the genre is its flexibility: ability to refer to reality - I would say - in crudo, but at the same time to the textual mechanisms themselves. And that is why it is able to create a community of recipients who appreciate knowledge they gain about contemporary Sweden while reading Millenium, but who also understand why a detective in ancient Athens is called Hercules Pontor and why it is funny. And why The Athenian Murders is not detective fiction at all...

\section{Bibliography}

Bradford Richard (2015), Crime Fiction. A Very Short Introduction, Oxford UP, Oxford.

Czubaj Mariusz (2010), Etnolog w Mieście Grzechu. Powieść kryminalna jako świadectwo antropologiczne, Oficynka, Gdańsk.

Detecting Texts. The Metaphysical Detective Story from Poe to Postmodernism (1999), eds. Meriva-

le P., Sweeney S.E., University of Pensylvania Press, Philadelphia.

Horowitz Anthony (2016), Magpie Murders, Orion Books, London.

- (2014), Moriarty, Orion Books, London. 
- (2017), The Word is Murder, Penguin Random House, London.

- (2019), The Sentence is Death, Arrow Books, London.

Kraska Mariusz (2013), Prosta sztuka zabijania. Figury czytania kryminatu, Fundacja Terytoria Książki, Gdańsk.

Malmgren Carl D. (2001), Anatomy of Murder: Mystery, Detective, and Crime Fiction, Bowling Green State University Popular Press, Bowling Green.

Marcus Laura (2009), Detection and literary fiction [in:] The Cambridge Companion to Crime Fiction, ed. Priestman M., Cambridge UP, Cambridge.

McHale Brian (1992), Constructing Postmodernism, Routladge, London-New York.

Merivale Patricia, Sweeney Susan Elizabeth (1999), The Games Afoot. On the Trial of the Metaphysical Detective Story [in:] Detecting Texts. The Metaphysical Detective Story from Poe to Postmodernism, eds. Merivale P., Sweeney S.E., University of Pensylvania Press, Philadelphia. Nilsson Louise, Damrosch David, D'haen Theo (2017), Introduction [in:] Crime Fiction as World Literature, eds. Nilsson L., Danrosch D., D’haen T., Bloomsbury Academic, New York-London.

Pristman Martin (2009), Introduction: crime fiction and detective story [in:] The Cambridge Companion to Crime Fiction, ed. Priestman M., Cambridge UP, Cambridge.

Scaggs John (2005), Crime Fiction, Routladge, London-New York.

Somoza José Carlos (2003), The Athenian Murders, transl. S. Soto, Abacus, London.

Sulis Gigliola (2010), A Polymorfic Genre and the Challenge of Globality [in:] Retold, Resold, Transformed. Crime Fiction in the Global Era, eds. Gregoriou C., Platten D., Sulis G., Mimesis International, Leeds.

Szajnert Danuta (2014), Apokryf literacki, “Zagadnienia Rodzajów Literackich”, t. 57, z. 2.

Tani Stefano (1984), The Doomed Detective: The Contribution of the Detective Novel to Postmodern American and Italian Fiction, Sothern Illinois UP, Carbondale.

Vickers Anita (2000), Stephanie Barron: (Re)inventing Jane Austen as Detective Dutchman [in:] The Detective as Historian: History and Art in Historical Crime Fiction, eds. Browne R.B., Kreiser Jr L.A., Bowling Green State University Popular Press, Bowling Green.

Worthington Heather (2011), Key Concepts in Crime Fiction, Palgrave Macmillan, London. 